\title{
Transaction
}

\section{Microbial Degradation of Disodium Terephthalate by Rhodococcus sp. 9-003}

\author{
Shichao Xu ${ }^{* 1}$, Masaya Yamashita*1, Junlin Yu ${ }^{* 2}$, and Shin-ichiro Suye ${ }^{* 2}$ \\ ${ }^{* 1}$ School of Environmental and Chemical Engineering, Tianjin Polytechnic University, Tianjin 300160, China \\ ${ }^{* 2}$ Department of Applied Chemistry and Biotechnology, Graduate School of Engineering, \\ University of Fukui, 3-9-1 Bunkyo, Fukui 910-8507, Japan
}

\begin{abstract}
Strain 9-003 was isolated from soil in the textile dying factory for its ability to assimilate disodium terephthalate (DT) as a carbon and energy source. Analysis of the base sequence of 16S ribosomal DNA allowed us to assign the bacterium to Rhodococcus sp., the strain reduced a total concentration of DT from 95.2 to $40.8 \mathrm{mM}$ for $7 \mathrm{~d}$, and showed highest degradation rate $(1.0 \mathrm{mM} / \mathrm{h})$ in $\mathrm{pH} 7.0$ culture broth at $25^{\circ} \mathrm{C}, 180 \mathrm{rpm}$. Oxygen uptake experiments with the resting cells showed the biodegradation process was aerobic. HPLC analysis of the culture broth revealed there was at least one intermediate-protocatechuic acid (PC) involved the microbial degradation process. Substrate spectrum indicated strain 9-003 assimilated DT, PC and p-hydroxybenzoic acid efficiently. The degradation path way of DT was discussed and we propose that DT was metabolized aerobically by Rhodococcus sp. 9-003 via PC.
\end{abstract}

(Received 20 Nov, 2011; Accepted 11 Mar, 2012)

\section{Introduction}

Poly (ethylene terephthalate) (PET) is one of the synthetic polymers that is widely used in the fiber industries for its good performance. However, a quantity of waste water containing a high concentration of disodium terephthalate (DT) is concomitantly generated during a weight loss process for improvement of their appearance and texture, during which they are heated with sodium hydroxide to hydrolyze the surface of the material [1].

Currently, waste water is usually handled by activated sludge treatment which is well suited for the treatment of variety of chemical substances. Some synthetic organic compounds can be degraded by active sludge [2]. In recent years, the biological degradation of terephthalate has been of interest and ecofriendly processing of synthetic polymer in the fiber industry has been given much attention because of environmental pollution [3]. The effective use of discharged terephthalate and its derivates is also desired. Several microorganisms have demonstrated the ability to degrade DT. Comamonas testosteroni T-2 can grow in medium and produces inducible enzymes that catalyze DT into (1R, 2S)-dihydroxy-3,5- cyclohexadiene-1,4-dicarboxylic acid and protocatechuic acid (PC) [4]. Terephthalate assimilation probability by Rhodococcus spacus GM-14 was also mentioned [5]. The terephthalate 1,2-dioxygenase system was found in cell free extract of Delftia suruhatensis strain T7 [6]. Recently, Phanerochaete chrysosporium was also reported to be able to degrade DT with its screened enzymes [7]. Moreover, during the DT degradation, PC was produced as an intermediate metabolite [8-16].

In the present study, we embarked on research attempting to convert or degrade terephthalate biologically into innocuous material, and a novel terephthalate-assimilating bacterium, Rhodococcus sp. strain 9-003 was isolated and characterized. This strain could degrade DT efficiently and PC was suggested as one of intermediate of DT metabolites, the degradation path way was offered similar to that of $C$. testosteroni T-2.E

\section{Materials and methods}

\subsection{Chemicals}

DT was purchased from Tokyo Kasei Kogyo, Co., (Tokyo, Japan). PC was purchased from Wako Pure Chemical Industries, Co., (Tokyo, Japan). All the other reagents were analytical grade and used without further purification.

\subsection{Screening and growth of DT degrading microorganisms}

The stock cultures in our laboratory and soil samples acquired from a textile dyeing factory in Fukui, Japan 
were used as the source for the screening of DT degrading microorganisms. One platinum loop of stock culture slant or $0.5 \mathrm{ml}$ of soil sample suspension were inoculated and cultured in $5 \mathrm{ml}$ DT medium (per liter; DT, $5.0 \mathrm{~g}$; $\mathrm{NH}_{4} \mathrm{NO}_{3}, 5.0 \mathrm{~g} ; \mathrm{KH}_{2} \mathrm{PO}_{4}, 1.0 \mathrm{~g} ; \mathrm{MgSO}_{4} \cdot 7 \mathrm{H}_{2} \mathrm{O}, 0.5 \mathrm{~g}$; $\mathrm{NaCl}, 0.5 \mathrm{~g}$; Yeast extract, $0.2 \mathrm{~g}$; $\mathrm{pH} 7.0$ ) in test tubes for 2 weeks at $30^{\circ} \mathrm{C}$ reciprocally. This procedure was repeated twice for subculturing. Then, the culture medium was put on an agar plate which contained the same component as described above. After cultivation, the isolation and purification of colonies was performed on the fresh agar plate repeatedly.

\subsection{Growth measurement}

The cell growth in aqueous medium was monitored by a spectrophotometer (UV-2010, Hitachi Co., Tokyo, Japan) by measuring the optical density at $660 \mathrm{~nm}$ (O.D. $660 \mathrm{~nm}$ ) with the medium as the reference.

\subsection{Preparation of crude enzymes}

Strain 9-003 was grown in $50 \mathrm{ml}$ DT medium in a $500-\mathrm{ml}$ flask on a rotary shaker, at $180 \mathrm{rpm}, 25^{\circ} \mathrm{C}$. The cells were harvested at c.a. 1.0 of O.D. $660 \mathrm{~nm}$, the supernatant was used as broth supernatant (fraction A); the precipitation was washed three times with $50 \mathrm{mM}$ potassium phosphate buffer ( $\mathrm{pH} 7.5$ ), and resuspended in the same buffer, then it was equally divided into two parts. One part of the suspension was used as cell suspension (fraction B); the second part was disrupted with a sonic oscillation (UCD-200, Cosmo Bio Co., Tokyo, Japan) for $15 \mathrm{~min}$, then sonicated solution was centrifuged at 10,000 rpm for $15 \mathrm{~min}$ at $4^{\circ} \mathrm{C}$. The supernatant was collected and used as cell free extract (fraction $\mathrm{C}$ ). The precipitate was washed 3 times and suspended with the same buffer, and used as cell debris (fraction D).

Crude enzyme solution $(2 \mathrm{ml})$ was incubated with $2 \mathrm{ml} 50 \mathrm{mM}$ potassium phosphate buffer ( $\mathrm{pH}$ 7.5) containing $6 \mathrm{mM} \mathrm{DT}$ at $25^{\circ} \mathrm{C}, 180 \mathrm{rpm}$ for $2 \mathrm{~h}$.

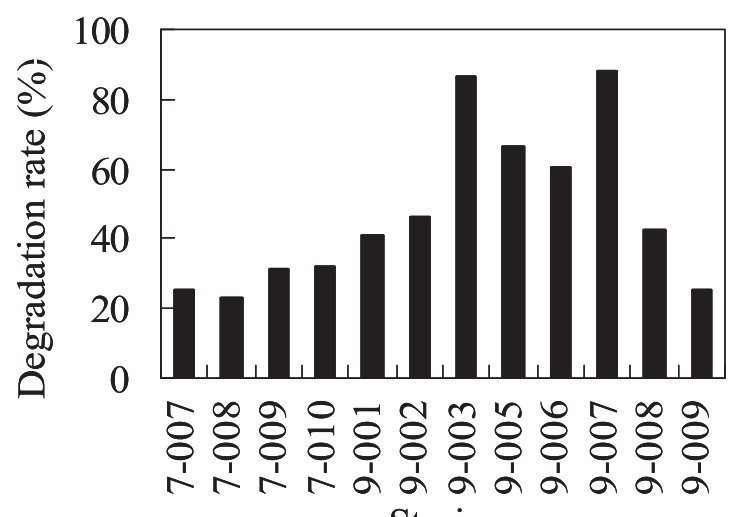

Fig. 1 Degradation of DT by isolated microorganisms (Initial concentration of DT is $10 \mathrm{~g} / \mathrm{l}$ ).

\subsection{Analytical methods}

HPLC was performed to determine the amounts of residual DT and PC in the broth and the reaction mixture. The sample was dissolved in $70 \%$ (v/v) methanol solution. HPLC was carried out with Cosmosil 5C18-AR-300 column $(250 \times 4$ mm i.d. ; Nacalai Tesque, Kyoto, Japan $)$ at $30^{\circ} \mathrm{C}$, the elution was at $0.5 \mathrm{ml} / \mathrm{min}$ with $70 \%$ methanol in $0.02 \mathrm{M}$ phosphoric acid solution. The absorbance of the eluent was monitored at $254 \mathrm{~nm}$. Integration was performed using a Hitachi D-2500 Reporting Integrator (Tokyo, Japan).

Oxygen consumption during DT degradation was measured with a galvanic cell-type oxygen electrode (Iijima Electric Industry Co., Tokyo, Japan). The reaction temperature was $25^{\circ} \mathrm{C}$, and all other operations and conditions were followed using the instruction manual given by the producer.

Protein concentration was determined by $\mathrm{BCA}$ method [17] with a BCA protein assay reagent (Techno Chemical Co., Japan) and bovine serum albumin as the standard.

\section{Results and discussion}

\subsection{Isolation of DT degrading microorganisms}

The screened microorganisms were cultivated in $2 \mathrm{ml}$ medium in a test tube at $25^{\circ} \mathrm{C}$ on a $180 \mathrm{rpm}$ rotary shaker for $7 \mathrm{~d}$. Some microorganisms were able to grow on DT medium among 500 stock cultures and 300 samples from soil and waste water. Eleven potent microorganisms were ultimately isolated and showed degradation rate from $23 \%$ to $86 \%$ (Fig. 1). Strain 9-002, 9-003, 9-005, 9-006 and 9-007 showed higher assimilation capabilities. Fig. 2 shows time course of DT degradation by these strains. Only strains 9003 and 9007 degraded DT completely for $168 \mathrm{~h}$ incubation. Strain 9003 was ultimately selected for further examination since it showed the fastest degradation rate on assimilation of DT.

\subsection{Identification and characterization of strain 9-003}

Strain 9-003 was morphologically and taxonomically identified by NCIMB Japan Co. Ltd (Shimizu, Japan). Table 1 shows the characteristics of strain 9-003. Bacterial identification based on ribosomal 16S DNA 500-bp sequence was simultaneously performed. The DNA sequencing indicated strain 9-003 was close matched with Rhodococcus globerulus, the percent difference between strain 9-003 and Rhodococcus globerulus was $0.20 \%$. The phylogenetic relationships 
Table 1 Characteristics of strain 9-003.

\begin{tabular}{cc}
\hline Gram stain & Positive \\
Spore & - \\
Shape Mobility & Rod-shaped bacilli \\
& $(0.8 \times 2.0-3.0 \mu \mathrm{m})$ \\
Oxidase activity & - \\
Catalase activity & + \\
Colony color & Straw yellow \\
Cultivation temp. & + \\
$30^{\circ} \mathrm{C}$ & + \\
$37^{\circ} \mathrm{C}$ & - \\
$45^{\circ} \mathrm{C}$ & + \\
\hline
\end{tabular}

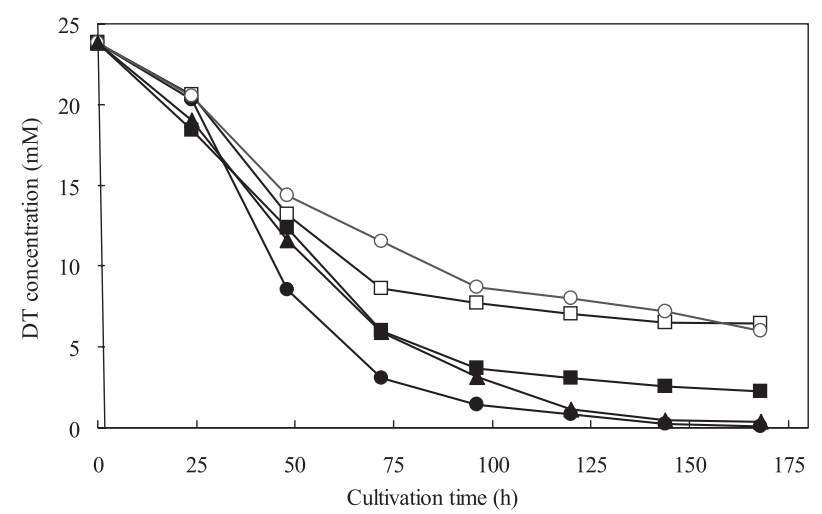

Fig. 2 Time course of DT degradation by various strains.

One loopful of the 5 strains were inoculated into $165 \mathrm{~mm} \times 16.5 \mathrm{~mm}$ (i.d.) test tube containing DT medium, respectively, and incubated on a rotary shaker, $180 \mathrm{rpm}$ for $48 \mathrm{~h}$ at $25^{\circ} \mathrm{C}$. A $1 \mathrm{ml}$ of culture (Optical density at $660 \mathrm{~nm}, 1.8-2.0$ ) was transferred to $500-\mathrm{ml}$ flasks containing $50 \mathrm{ml}$ of DT medium respectively, and then they were incubated on a rotary shaker, $180 \mathrm{rpm}$, for $168 \mathrm{~h}$ at $25^{\circ} \mathrm{C}$, the residual DT was measured periodically by HPLC. Symbols : ( $\square), 9002$; (•), $9003 ;(\mathbf{\square}), 9005 ;(\bigcirc), 9006 ;(\mathbf{A}), 9007$.

were analyzed by the neighbor-joining method, and the results also supported that strain 9-003 was near-perfect match of the Rhodococcus genus and globerulus species [18-20]. Analysis of gene sequence and phylogenetic relationships suggested strain $9-003$ is a member of Rhodococcus sp.

\subsection{Biodegradation of DT by Rhodococcus sp. 9- 003}

Time course of high concentration of DT degradation by Rhodococcus sp. 9-003 and cell growth in culture broth were investigated. As shown in Fig. 3, strain 9-003 had nearly no lag period before growth start, and the cell growth (O.D. $660 \mathrm{~nm}$ ) exceeded c.a. 1.0 after $24 \mathrm{~h}$ cultivation, which indicated cell growth was not

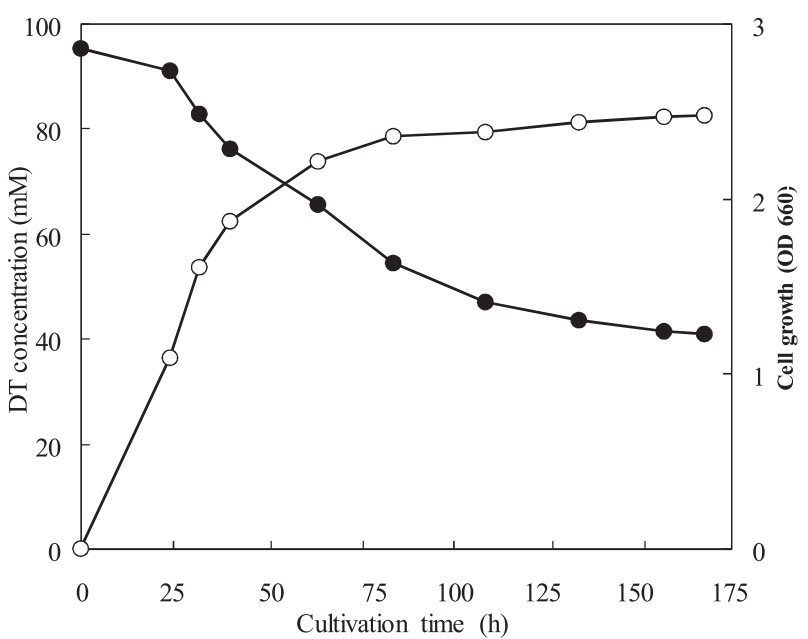

Fig. 3 Time course of DT degradation by strain 9-003. The cultivation was carried out under standard conditions except for the DT concentration. Symbols : (O), DT concentration; $(\bigcirc)$, Cell growth.

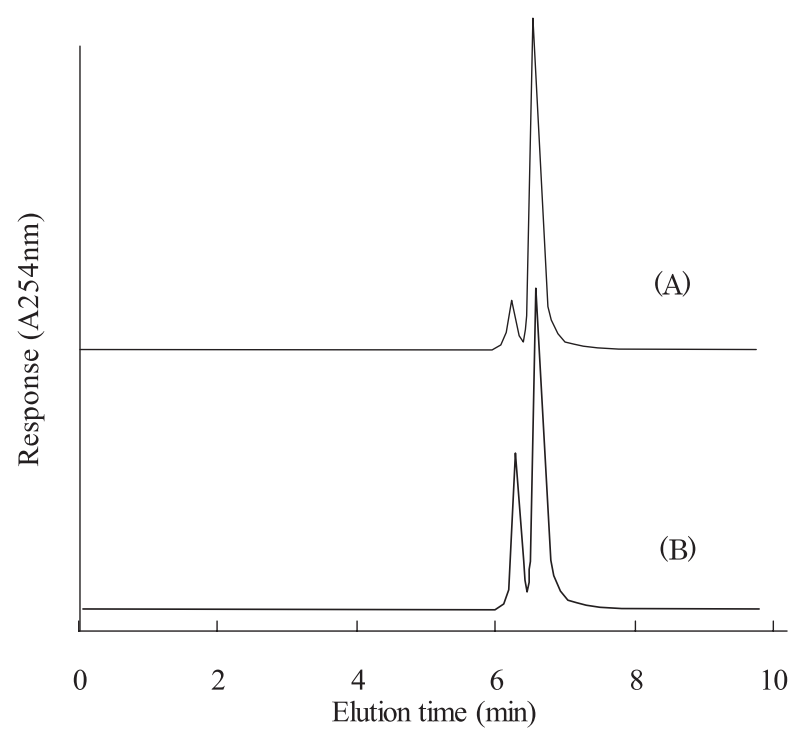

Fig. 4 HPLC elution profile of culture broth of Rhodococcus sp. 9-003.

(A): Culture broth; (B): Culture broth + authentic PC.

inhibited by high concentration of DT. Degradation of DT reached $54.4 \mathrm{mM}(57.1 \%)$ from initial concentration of $95.2 \mathrm{mM}$ for $168 \mathrm{~h}$ by Rhodococcus sp. 9-003. Degradation accelerated between $24 \mathrm{~h}$ and $32 \mathrm{~h}$, and the maximum degradation velocity was $1 \mathrm{mM} / \mathrm{h}$. Therefore, the results indicate that the degradation rate of DT by Rhodococcus sp. 9-003 was faster than that those of previous reports $[8,9]$. The degradation rate slowed down after $96 \mathrm{~h}$, this fact is probably related to the formation of intermediate degraded products and the temporary accumulation in culture medium under high concentration of DT $[21,22]$. Furthermore, the increasing in $\mathrm{pH}$ during the biodegradation can cause an inhibitory effect [2], and after maintaining the $\mathrm{pH}$ at 7.5 using phosphate potassium 


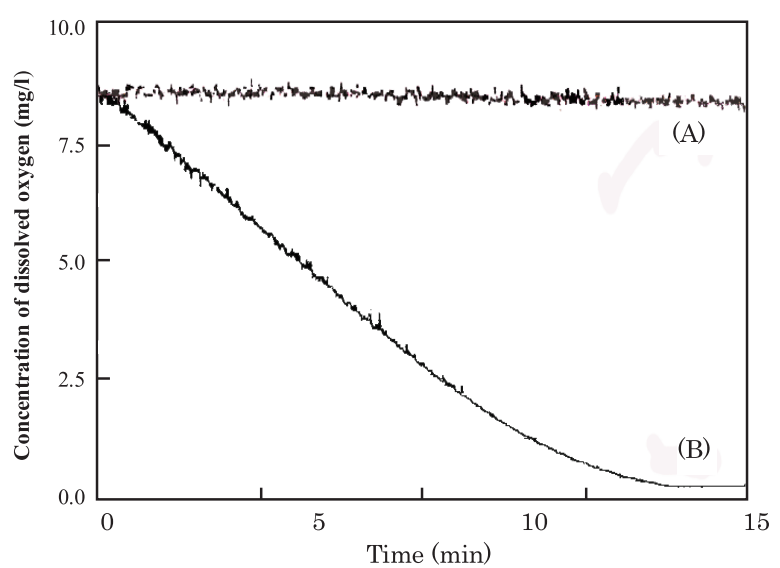

Fig. 5 Oxygen consumption of Rhodococcus sp. 9-003 during DT degradation. (A) : Control, $1.8 \mathrm{ml}$ of $50 \mathrm{mM}, \mathrm{pH} 7.5$ potassium phosphate buffer containing $3 \mathrm{mM} \mathrm{NADH}, 1 \mathrm{mM} \mathrm{FeSO}_{4}$, reaction was started by adding $0.2 \mathrm{ml}$ of cell suspension of Rhodococcus sp. 9-003; (B): Sample, $1.8 \mathrm{ml}$ of $50 \mathrm{mM}$, pH 7.5 potassium phosphate buffer containing $2 \mathrm{mM} \mathrm{DT}, 3 \mathrm{mM} \mathrm{NADH}$, $1 \mathrm{mM} \mathrm{FeSO}_{4}$, and the reaction was started by adding $0.2 \mathrm{ml}$ of cell suspension of Rhodococcus sp. 9-003. The reaction was carried out at $25^{\circ} \mathrm{C}, 180 \mathrm{rpm}$ for $20 \mathrm{~min}$.

Table 2 Growth of Rhodococcus sp. 9-003 on various substrates.

\begin{tabular}{lc}
\hline \multicolumn{1}{c}{ Carbon source } & $\begin{array}{c}\text { Cell growth } \\
(\text { O.D. } 660 \mathrm{~nm})\end{array}$ \\
\hline Ethyleneglycol dibenzoate & 0.718 \\
Dimethyl terephthalate & 0.289 \\
Diethyl terephthalate & 0.106 \\
Disodium terephthalate & 1.563 \\
Phthalic benzoic acid & 0.323 \\
Benzoic acid & 0.763 \\
$p$-Hydroxybenzoic acid & 1.836 \\
Protocatechuic acid & 2.162 \\
\hline
\end{tabular}

buffer with low concentration of DT, complete degradation can be observed.

When the culture broth was analyzed on HPLC, two major peaks appeared at 6.7 and $7.0 \mathrm{~min}$ respectively (Fig. 4A). One peak at 7.0 min was DT, another peak was identified as PC by HPLC after performing the examination with adding authentic $\mathrm{PC}$ as an internal standard (Fig. 4B), because they showed same retention time at $6.7 \mathrm{~min}$. This result also supported that $\mathrm{PC}$ was generally accepted intermediate during biodegradation of aromatic compounds [8-16]. The result inferred that DT was likely degraded into cleavage compounds via $\mathrm{PC}$ by Rhodococcus sp. 9-003.

DT degradation with resting cells of strain 9-003 was

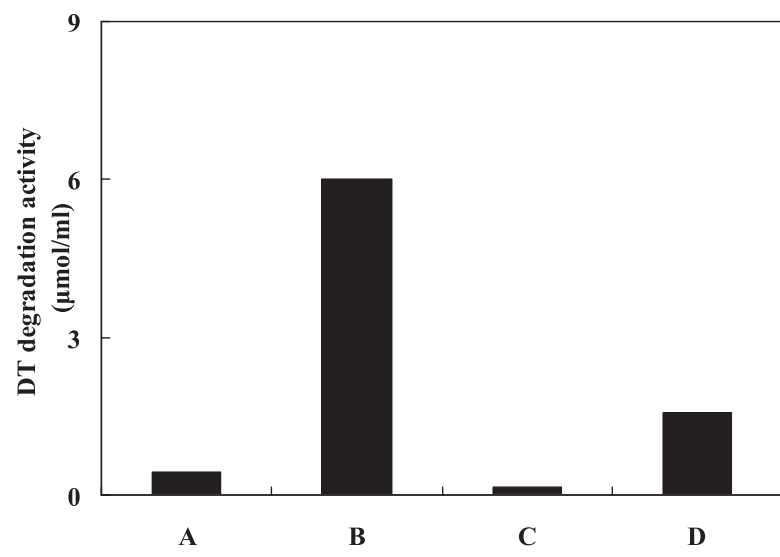

Fig. 6 DT degradation by crude enzymes fractions from Rhodococcus sp. 9-003. (A): Broth supernatant ; (B) : Cell suspension ; (C) : Cell free extract ; (D) : Cell debris of cell disruption.

also carried out and the preparation of resting cells was in the same manner for cell suspension as described in Materials and Methods section. The resting cells of Rhodococcus sp. 9-003 degraded $22 \mathrm{mM}$ (91.7\%) of DT from the initial concentration of $24 \mathrm{mM}$ for $72 \mathrm{~h}$ at $\mathrm{pH} 7.5$ in $50 \mathrm{mM}$ potassium phosphate buffer, and after $120 \mathrm{~h}$ incubation, DT was degraded completely. In addition, we investigated the oxygen consumption during DT degradation by resting cell. Resting cells did not show any oxygen consumption in $50 \mathrm{mM}$ potassium phosphate buffer solution without DT (Fig. 5A). However, in the presence of $2 \mathrm{mM} \mathrm{DT}$, they consumed dissolved oxygen rapidly (Fig. 5B). These results show that the degradation process is aerobic and DT was degraded and utilized by several oxygenases. The biodegradation rate of DT on the basis of oxygen consumption was estimated to be $14.2 \%$.

\subsection{Substrate specificity}

Various aromatic compounds were used as sole carbon source to evaluate the specific degradation activity of Rhodococcus sp. 9-003. The degradation was performed in $4 \mathrm{ml}$ of DT medium except for the indicated substrate at $25^{\circ} \mathrm{C}, 180 \mathrm{rpm}$ for $7 \mathrm{~d}$ in test tubes, the growth rate was used to indicate the activity against the various substrates by measuring O.D. $660 \mathrm{~nm}$, the substrate spectrum of strain 9-003 includes mono-, di- as well as tri-substituted aromatic compounds, as showed in Table 2. Protocatechuic acid was the best substrate, then followed by $p$-hydroxybenzoic acid and DT, namely, protocatechuic acid and $p$-hydroxybenzoic acid were metabolized more easily by Rhodococcus sp. 9-003 than that of DT, and this also supports that PC may be one of the metabolic intermediates that can be degraded rapidly during the biodegradation process [8-15].

\subsection{Distribution of DT degrading enzyme}

To investigate distribution of DT degrading enzyme, 
various crude enzyme fractions were prepared and DT degradation activities were measured. Cell suspension (fraction B) exhibited the highest activity on degradation of DT (Fig. 6). Aromatic compounds degrading enzyme were often found in cell free extract $[4,5,23,24]$. In contrast, cell free extract of Rhodococcus sp. 9-003 (fraction C) showed low DT degradation activity. These results suggest that DT degradation enzyme might be a unstable membrane bound enzyme and lost its activity rapidly [25] in cell disruption process. Further works are in progress to isolate and purify the DT degrading enzyme.

In conclusion, DT-utilizing bacteria strain 9-003 was screened and identified as Rhodococcus sp. The degradation path way of DT was also suggested as an aerobic ring-cleavage via $\mathrm{PC}$ as intermediate. Rhodococcus sp. could be used for utilization of DT from fiber weight loss processing.

\section{References}

1. D. Sugimori, T. Dake, S. Nakamura, Biosci. Biotechnol. Biochem., 64, 2709 (2000).

2. T. Kimura, Y. Ito, J. Biosci. Bioengineer., 91, 416 (2001).

3. S. Suye, Y. Takahashi, S. Fujita, M.Sakakibara, Sen ’i Gakkaishi, 12, 58 (2002).

4. H. R. Schlafli, M. A. Weiss, T. Leisinger, $J$. Biotechnol., 176, 6644 (1994).

5. G. M. Zaitsev, J. S. Uotila, I. V. Tsitko, A.G. Lobanok, M. S. Salkinoja-Salonen, Appl. Environ. Microbiol., 61, 4191 (1995).

6. T. Shigematsu, K. Yumihara, Y. Ueda, S. Morimura, K. Kida, FEMS Microb. Lett., 220, 255 (2003).

7. J. Yan, S. P. Cheng, X. X. Zhang, L. Shi, C. J. Zhu, Bull. Environ. Contam. Toxicol., 72, 387 (2004).
8. G. Engelhardt, P. R. Wallnofer, H. G. Rast, Achieves Microbiol., 109, 109 (1976).

9. T. B. Karegoudar, B. G. Pujar, FEMS Microb. Lett., 30, 217 (1985).

10. Y. Wang, Y. Zhou, G. J. Zylstra, Environ.l Health Perspec. 103, 9 (1995).

11. J. Heider, G. Fuchs, Eur. J. Biochem., 243, 577 (1997).

12. R. A. Kanaly S. Harayama, J. Bacteriol ., 182, 2059 (2000).

13. E. Diaz, A. Ferrandez, M. A. Prieto, J. Garcia, Microb. Mol. Biol. Rev., MMBR 65, 523 (2001).

14. D. Sugimori, T. Sekiguchi, Sen'i Gakkaishi 58, 188 (2002).

15. O. Cinar, Bioprocess. Biosys., Engineer., 26, 341 (2004).

16. R. Rabus, M. Kube, J. Heider, A. Beck, K. Heitmann, F. Widdel, R. Reinhardt, Arch. Microb., 183, 27 (2005).

17. M. M. Bradford, Anal. Biochem ., 72, 248 (1976).

18. T. Palys, L. K. Nakamura, F. M. Cohan, Int. J. Syst. Bacteriol ., 47, 1145 (1997).

19. M. Drancourt, C. Bollet, A. Carlioz, R. Martelin, J. Gayral, D. Raoult, J. Clin. Microb. 38, 3623 (2000).

20. J. L. Cloud, H. Neal, R. Rosenberry, C. Y. Turenne, M. Jama, D. R. Hillyard, K. C. Carroll, J. Clinc. Microb., 40, 400 (2002).

21. P. Steinle, G. Stucki, R. Stettler, K. W. Hanselmann, Appl. Environ. Microbiol . 64, 2566 (1998).

22. E. Mendonca, A. Martins, A. M. Anselmo, Electron. J. Biotechnol., 7, 38 (2004).

24. O. Cinar, Process Biochem., 40, 1409 (2005).

25. O. Cinar, FEMS Microb. Lett., 231, 59 (2004).

23. T. Yoshida, Y. Hayakawa, T. Matsui, T., Nagasawa, Arch. Microbiol ., 181, 391 (2004). 